\title{
Effects of Organizational Commitment and Internal Control on Accounting Information System Quality and Its Impact on Accounting Information Quality (Research on Trading Companies listed in PT. Solusi Akuntansi Indonesia)
}

\author{
Devi Eryana*, Fardinal
}

Master of Accounting, Economy Faculty, Mercu Buana University Indonesia

DOI: $\underline{10.36348 / \text { sb.2019.v05i12.007 }}$ | Received: 05.12.2019| Accepted: 14.12.2019| Published: 20.12.2019

*Corresponding author: Devi Eryana

\section{Abstract}

This research aims to find truth through testing (confirmation) on effects of organizational commitment and internal control on accounting information system quality and its impact on accounting information quality. The results are expected to proof that the model can become a solution to accounting information system quality and accounting information quality. The data was obtained by distributing questionnaires to 365 trading companies registered in PT. Solusi Akuntansi Indonesia. The data was statistically processed using Linear Regression. The research method was survey research to obtain a causal answer through an analysis of causes-effects on accounting information system quality and accounting information quality. The result indicates that organizational commitment and internal control have positive and significant effects on accounting information system quality. Further, it affects accounting information quality. The research implication indicates that organizational commitment and internal control are important to produce a quality accounting information system. So, it will produce quality accounting information as well.

Keywords: Organizational Commitment, Internal Control, Accounting Information System Quality, Accounting Information Quality.

Copyright @ 2019: This is an open-access article distributed under the terms of the Creative Commons Attribution license which permits unrestricted use, distribution, and reproduction in any medium for non-commercial use (NonCommercial, or CC-BY-NC) provided the original author and source are credited.

\section{INTRODUCTION}

Competition level among companies is getting harder in business world. Changes in consumer taste, technological advancement, and socio-economic create challenges and opportunities in business. Information system development affects business process so business can run easier. Business process can run faster through the assistance of a system. Therefore, it can increase competitiveness [1]. Companies must be able to take advantage of their capabilities to win the competition and obtain maximum possible profits as one of the company's objectives.

Accounting information system as a computerbased system is designed to convert accounting data into information [2]. Furthermore, Hall [3] stated that fundamental purpose of accounting information system presents accounting information to external parties, managements, and employees. Azhar Susanto [4] stated relevant opinion that fundamental role of accounting information system in an organization is to produce quality accounting information. Sacer Ivana M et al. [5] also stated that quality accounting information was obtained from application of quality accounting information system.

The existence of accounting software in a company has changed the pattern of existing data processing into information in a manual environment. The same changes can also be seen from end-user perspective as a party operating the accounting software. These environmental changes may cause a culture shock which requires trainings to familiarize the users with their new environment [6].

According to Larsen [7], many factors can affect a successful implementation of accounting information system. One of the most important factor is organizational commitment because the core of 
organizational commitment is manager's engagement and loyalty to the company that encourage them to always work hard in various company situations [8].

According to Hahn and Herman [9], one of the methods to improve information processing is to increase the level of member involvement. Therefore, one way to create this situation is improving their commitment. Organizational commitment means more than passive loyalty but involving active relationship and employees' desire to provide meaningful contribution to their organization.

Beside the organizational commitment, a successful implementation of accounting information system is also affected by another major factor that is internal control. Weak internal control system provides opportunities for fraud or corruption [10].

Azhar Susanto [11] stated that the first defense against financial fraud is internal control, in other words, a comprehensive internal control system. It must be implemented thoroughly and regularly to monitor organization activities as an important step to maintain and detect the risk of loss caused by financial fraud.

The internal control system consists of policies and procedures designed to provide management with reasonable certainty that company has achieved its goals and objectives [2]. It is designed to monitor and maintain accounting information system quality and safety to perform input, process, and output activities [12]. Further, creating an accounting information system to function as expected by the management, it is required an internal control [4].

Based on the description above, the researcher is interested in finding empirical evidence about the effects of organizational commitment and internal control on accounting information system quality and its impact on accounting information quality on trading companies registered in PT. Solusi Akuntansi Indonesia because they are accounting software users.

\section{LITERATURE REVIEW, THEORETICAL FRAMEWORK, AND HYPOTHESIS}

\section{Literature review \\ Accounting Information System Quality}

According to Azhar Susanto [11], Romney and Steinbart [13], Weygandt, et al. [14] a system collects, records, saves, and processes data to produce information for decision makers.

So, it can be concluded that accounting information system is an activity to process data by identifying, collecting, and recording, saving, and processing data in a system to produce information to be used by internal and external users as the material for making decisions.
According to Azhar Susanto [11], Ralph and George [15] a quality information system is usually flexible, efficient, accessible and timely. Meanwhile, according to Laudon and Laudon [16] a quality information system is an information system that combining technical efficiency with sensitivity for human and organizational needs, causing high job satisfaction and productivity.

Based on these understandings, a quality accounting information system is efficient, flexible, accessible and timely to provide job satisfaction and high productivity.

The dimensions and indicators used in the concept of a quality accounting information system in this research are:

- Efficiency: using resources optimally [11], Laudon and Laudon [16], Ralph and George [15], DeLone and McLean [17].

- Accessibility: Information that is easy to be accessed from an accounting information system [18], DeLone and McLean [17], Ralph and George [15].

- Integration: all components in the system (hardware, software, brainware, database, procedure and communication network) synergize in the accounting information system to process financial data into financial information needed by management for the decision making process [11], Wixom and Todd [18].

\section{Accounting Information Quality}

According to Baltzan [19], Gelinas et al. [20], Sulistyoningsih [21] "Accounting information is said to be a quality one if it has been able to disclose material information in a complete and accurate manner including the relevant essential events". Accounting information provided in the form of a company financial statement is a medium of communication between the company business activities and the parties with an interest in financial position and company's business development. Accounting information uses depend on the users.

From the explanation above, it can be said that a quality accounting information disclosing complete and accurate material information to provide benefits for the decision makers.

The dimensions and indicators used for each characteristic of accounting information quality in this research are:

- Relevant: the provided information must be in accordance with individuals' need at various levels and sections in organization $[4,16,12,22]$

- Accurate: information must reflect real situation, testing the accuracy s conducted by two or more 
people. If the test produces the same results, the data is considered accurate $[4,23,16,22,12]$

- Timely: information must be available when it is needed, not tomorrow or not in a few hours $[4,23$, $16,23,12]$

- Complete: information must be given in full, for example sales information without specifying the month or invoice $[11,23,16,15,12]$.

\section{Organizational Commitment}

According to Ria and Daman [24]; John A Wagner and Hollenbeck [6]; Moorhead and Griffin [25]; Robbins and Judge [26]; organizational commitment is the attitude of employees' loyalty to the organization, by staying in it, achieving organizational goals and not having desire to leave the organization for any reason.

Based on the understanding above, organizational commitment is a level where a person is bound to the organization, stay, and willing to do more to achieve organizational goals and uphold organizational values.

The dimensions and indicators used for organizational commitment variable are:

- Affective commitment: individuals' emotional approach in their involvement with the organization, so, individuals will always be connected to the organization Mayer and Allen [27], Ria and Darman [24], Robbins and Judge [28], Colquitt, et al. [29].

- Continuance commitment): desire to survive in the organization, so, individuals feel they always be connected to the organization. Colquitt, et al. [30], (Mayer and Allen [27], Ria and Darman [24], Robbins and Judge [31].

- Normative commitment: surviving in an organization for moral and ethical reasons Robbins and Judge [32], Colquitt, et al. [30], (Mayer and Allen [27], Ria and Darman [24].

\section{Internal Control}

According to Romney and Steinbart [13], Haryono [33], Mulyadi [34], internal control system includes organizational structure, coordinated methods and measures to maintain organizational assets, checking of the accuracy and reliability of accounting data, encouraging efficiency and compliance with management policies.

Meanwhile, according to The Committee of Sponsoring Organizations of The Treadway Commission (COSO) in Executive Summary [35]: "Internal control is a process, effected by an entity's board of directors, manage-ment, and other personnel, designed to provide reasonable assurance regarding the achievement of objectives relating to operations, reporting, and compliance".
From the understandings above, internal control is a way containing a set of policies and regulations to guide, supervise, and protect company resources to avoid any forms of abuse and misuse. In other words, it is conducted to oversee whether or not theoperational activities are running on track in accordance with the policies and regulations set by the company.

\section{The dimensions and indicators used in internal control are}

Control environment: establishing organizational atmosphere and providing awareness about the need of control for an organization Azhar Susanto [11], Valery G. Kumaat [22], COSO [35], Alvin, Randal and Mark [36] consists of:

- Integrity and ethics

- Commitment to competency

- Participation of board of directors or audit committee

- Pphilosophy and operating style pf management

- Organizational structure

Human resources policiesControl activities: policies and procedures to ensure that the activities in overcoming control risk have been conducted to achieve certain objectives (AgoesA goes Sukrisno [29], Alvin, Randal and Mark [36], Hery [23].

\section{THEORETICAL FRAMEWORK Effects of Organizational Commitment on Accounting Information System Quality}

According to Hahn and Herman [37], one method to improve information processing is to increase the involvement level of the members. Increasing members' involvement in organization can be achieved by increasing the organizational commitment. It means more than passive loyalty but involving active relationship and employees' desire to provide meaningful contributions to their organization. A significant contribution in terms of managing state finance is producing transparent financial statement to present and disclose all financial transaction and assets owned by the state to obtain unqualified opinion (WTP).

The conclusions of the previous research regarding the effects of organizational commitment on accounting information system quality by Rapina [31], Yenni Carolina [29], Azhar Susanto [4], Azmi and Sri Mulyani [14], and Nunung Nurhayati [23] stated that Organizational commitment affects accounting information system quality.

\section{Effects of Internal Control on Accounting Information System Quality}

Accounting information system is affected by several factors including user involvement in information system development, organizational size, 
top management support, formalization of SIA development committee, and training and education program for SIA users, SIA control committee, and SIA department location [38]. Atria et al. [39] stated strengthening human resources is important in implementing accrual-based SAP by increasing accounting personnel competence in handling financial management and increasing overseeing SAP committees in a rational manner. Both aspects greatly affect information quality produced by a company.

The conclusions of the orevious studies on the effects of internal control on accounting information system quality by Winda Rimayanti [40], Aceng and Meilani [9], Fardinal [25], Syafrida Dwi [36] stated that Internal Control affects Accounting Information System Quality.

\section{Effects of Accounting Information System Quality on Accounting Information Quality}

Information system is needed by companies to process data into information. One of the information systems in the company is an accounting information system. It processes data in the form of economic data into accounting information. This information is the basis for managers and non-managers to decide whether they must perform some actions or not. Quality information is produced by a good information system. Further, it will not mislead the decision makers when managing their organization, and being able to detect early potential risks (Early Warning System) [11]. Taufik Saleh et al. [24] stated the better the implemented information system, the more reliable, relevant, and timely accounting information. It is because there is a positive relationship between information system quality and accounting information quality.

The conclusions of the previous studies regarding the effects of accounting information system quality on accounting information quality by Syafrida Dwi [36], Aceng and Meilani [9], Rapina [28], Rapina [26], Ramdany [32], Franta Evaline [39] and Taufik Akbar [24] stated that accounting information system quality affects accounting information quality.

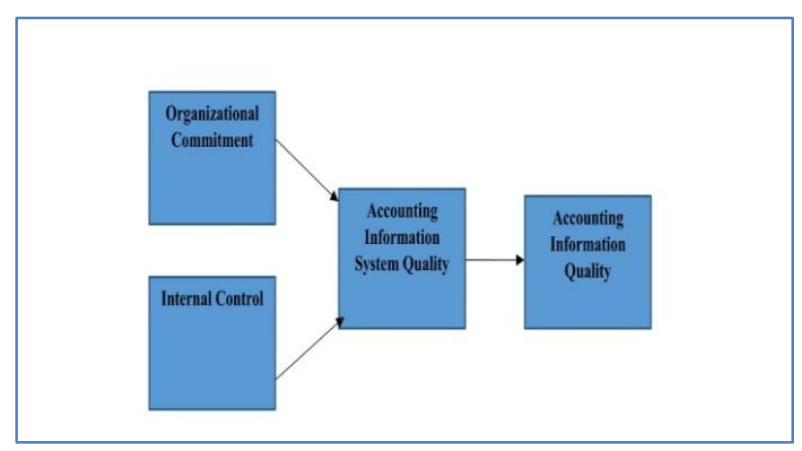

\section{HYPOTHESIS}

Hypotheses are temporary answers on presumptive problems because they still need to be proven. Scientific hypotheses try to propose temporary answers to prospective problems. The following are formulated hypotheses in this research:

H1 : Organizational Commitment affects Accounting Information System Quality

H2 : Internal Control affects Accounting Information System Quality

H3 : Accounting Information System Quality Affects Accounting Information Quality

\section{RESEARCH DESIGN AND METHOD}

Research method was method used by the researcher to solve problems [41]. Meanwhile, Jujun S. Suriasumantri [42] stated it was a method used in research. The research method in this study was survey. Sekaran and Bougie [22] stated that survey collected information from people acted as the sources of information. So, observation facts related to people, events, or certain situations could be described, compared, and explained.

Independent variable in this study was Organizational Commitment and Internal Control, while dependent variable was Accounting Information System Quality and Accounting Information Quality. According to Sugiyono [1] variables were those affecting or causing changes or emergence of dependent variable (bound). Meanwhile, according to Suharsimi Arikunto [43] variables were research objects, or research focus. Definition of variable according to Juliansyah Noor [44] was an activity to test hypotheses. It was conducted by testing the compatibility between theories and empirical facts in real world.

In this research, unit of analysis was each Trading Company Registered in PT. Solusi Akuntansi Indonesia. The researcher selected Trading Companies registered in PT. Solusi Akuntansi Indonesia because Accounting Information System becomes a very important part for the interest of outside and inside organization. In addition, the researcher did not find any similar research that chosing trading companies as the research object.

Population according to Sekaran and Bougie [22] was the entire group of people, events, or things of interest that the researchers wishes to investigate". Based on this definition, population in this study were all trading companies registered in PT. Solusi Akuntansi Indonesia. The sampling was based on the number of 365 Trading Companies registered in PT. Solusi Akuntansi Indonesia.

The sampling techniquein this research was a probability technique with simple random sampling. Simple random sampling according to Sekaran and 
Bougie [22] was a random sample selection technique for population members without considering the strata in the population, and each member in the population had same opportunity to be selected.

The method used to determine samples by the researcher was Slovin approach, with tolerable error limit of $5 \%$. So, it could be seen that prospective sample in this research came from a population of 365 , with 190 trading companies registered in PT. Solusi Akuntansi Indonesia. Further, the respondents were Accounting Departments, specifically the Accounting Managers.

Data collection was conducted by sending a questionnaire through electronic mail, in which each unit of analysis would receive 1 questionnaire addressed to the Accounting Manager.

Data analysis in this research was descriptive and verification analysis. Descriptive analysis aimed to obtain descriptive explanation regarding research variables characteristic. Variative analysis aimed to determine relationship among variables through hypothesis testing using Structural Equation Model (SEM) with Partial Least Square (PLS) approach.

Verification analysis was conducted through SEM based on variance, that was using PLS. SEM PLS was chosen because the measurement model was formed by variables with formative indicators.

\section{RESULT AND DISCUSION}

The result was taken from the questionnaires distributed to 365 trading companies registered in PT. Solusi Akuntansi Indonesia. The respondents in this research were all people involved in presenting accounting information in the Accounting Department that were the Accounting Managers. From the total questionnaire, 190 had been replied and could be processed which then tested and analyzed.

Three measurement criteria were used in the data analysis technique by SmartPLS to assess the model. The three measurements were Convergent validity, reliability test (Composite reliability and Chronbach Alpha) and Discriminant validity.

\section{Convergent Validity}

Validity Test in this research was conducted on each indicator by assessing its Convergent validity and Discriminant validity.

Based on the Convergent validity test, the indicator is said to be valid if the loading value between indicators and its dimension is 0.7 at least. The loading value of the variables in this research were all indicators of organizational commitment, internal control, accounting information system quality and accounting information quality that showed a loading value greater than 0.7. Therefore, indicators in organizational commitment variable can be said to be valid to measure its dimension.

\section{Composite Reliability}

Besides seeing the loading factor value as a validity test, there is a reliability test in measurement model. Reliability test is conducted to prove accuracy, consistency and instruments accuracy in measuring a variable. In PLS - SEM by using Smart PL S, to measure the variables' reliability, it was conducted in two ways, by Cronbach's Alpha and Composite reliability. However, Cronbach's Alpha in testing the variables' reliability gave a lower value (under estimate) so; it was recommended to use Composite Reliability.

Composite Reliability and Cronbach Alpha calculation can be seen in the following table:

Table-4.1: Results of Reliability Test on Indicator Construct to Dimension

\begin{tabular}{|l|c|c|}
\hline \multicolumn{1}{|c|}{ Dimension } & \multicolumn{1}{c|}{$\begin{array}{c}\text { Cronbach's } \\
\text { Alpha }\end{array}$} & $\begin{array}{c}\text { Composite } \\
\text { Reliability }\end{array}$ \\
\hline Affective Commitment & 0.864 & 0.907 \\
\hline Continuance commitment & 0.879 & 0.926 \\
\hline Normative Commitment & 0.828 & 0.897 \\
\hline Control Environment & 0.901 & 0.931 \\
\hline Controlling Activities & 0.877 & 0.916 \\
\hline Efficiency & 0.818 & 0.892 \\
\hline Ease of Access & 0.843 & 0.906 \\
\hline Integration & 0.800 & 0.909 \\
\hline Relevant & 0.812 & 0.889 \\
\hline Accuracy & 0.785 & 0.875 \\
\hline On Time & 0.836 & 0.901 \\
\hline Complete & 0.830 & 0.898 \\
\hline
\end{tabular}

Based on table 4.1, it can be seen that Composite Reliability value is greater than 0.8 and Cronbach Alpha value is greater than 0.7. Therefore, it can be said that all indicators in this study are reliable to measure their dimensions. 
Beside indicator reliability test on its dimensions, a reliability test was also conducted on the dimensions which can be seen through the summary presented in table 4.2 below:

Table-4.2: Validity and Reliability of Variables

\begin{tabular}{|l|c|c|c|}
\hline \multicolumn{1}{|c|}{ Variable } & $\begin{array}{c}\text { Cronbach's } \\
\text { Alpha }\end{array}$ & $\begin{array}{c}\text { Composite } \\
\text { Reliability }\end{array}$ & $\begin{array}{c}\text { Average } \\
\text { variance } \\
\text { Extracted } \\
\text { (AVE) }\end{array}$ \\
\hline Organizational Commitment & 0.947 & 0.955 & 0.648 \\
\hline Internal Control & 0.942 & 0.952 & 0.711 \\
\hline $\begin{array}{l}\text { Accounting Information } \\
\text { Quality }\end{array}$ & 0.950 & 0.957 & 0.648 \\
\hline $\begin{array}{l}\text { Accounting Information } \\
\text { System Quality }\end{array}$ & 0.937 & 0.948 & 0.695 \\
\hline
\end{tabular}

From table 4.2 above, it can be seen that all variables value in reliability test using Cronbach's Alpha or Composite Reliability is $>0.7$. Therefore, it can be concluded that tested variables are valid and reliable, so, it can be continued to test the structural model.

\section{Second Order Confirmatory Factor Analysis}

Second order confirmatory analysis is a theoretical relationship between latent variables or high order construct and underlying construct dimension [3].

To assess the significance between variables, the researcher conducted bootstrapping procedure. The bootstrap procedure used all original samples to perform resampling. In bootstrap resampling method, the significance value was t-value of 1.96 (significance level = 5)

\section{Structural Model Analysis (Inner Model)}

Structural evaluation model or inner model aims to predict the relationship between latent variables. The structural model was evaluated by looking at percentage variance by looking at R-Square value for endogenous latent variables and AVE for predictiveness by using resampling procedures such as jackknifing and bootstrapping to obtain stability from estimation.

\section{R-Square}

Table-4.3: Dependent Variable $\mathbf{R}^{2}$ Value

\begin{tabular}{|l|c|}
\hline \multicolumn{1}{|c|}{ Dependent Variable } & R Square \\
\hline Accounting Information Quality & 0.940 \\
\hline $\begin{array}{l}\text { Accounting Information System } \\
\text { Quality }\end{array}$ & 0.941 \\
\hline
\end{tabular}

Based on table 4.3 , it can be concluded that model of organizational commitment effect and Internal Control on information system quality produced a value of 0.941 . It can be interpreted that accounting information system quality explained by organizational commitment and Internal Control is $94.1 \%$, while the rest is explained by other variables outside this research. Likewise, model of organizational commitment and Internal Control effect on accounting information quality produced a value of 0.940 , which can be interpreted that quality accounting information explained by organizational commitment and Internal Control variable is $94 \%$, while the rest is explained by other variables outside this research.

\section{Hypothesis Test}

Whether a hypothesis is accepted or rejected can be performed by paying attention to significance values among variables, $t$-statistics and $p$-values. Therefore, estimated measurements and standard errors are no longer calculated by statistical assumption, but based on empirical observation. In the bootstraping method in this research, the hypothesis is accepted if significance value of t-values $>1.96$ or $p$-values $<0.05$, then $\mathrm{Ha}$ is accepted and Ho is rejected and vice versa.

Tabel-4.4: Path Coefficient

\begin{tabular}{|c|c|c|c|c|c|}
\hline Variable & $\begin{array}{c}\text { Original } \\
\text { Sample } \\
\text { (0) }\end{array}$ & $\begin{array}{c}\text { Sample } \\
\text { Mean (M) }\end{array}$ & $\begin{array}{l}\text { Standard } \\
\text { Deviation } \\
\text { (STDEV) }\end{array}$ & $\begin{array}{l}\text { T Statistics } \\
\text { (O/STDEV) }\end{array}$ & $\begin{array}{c}\text { P } \\
\text { Values }\end{array}$ \\
\hline $\begin{array}{l}\text { Accounting Information } \\
\text { System Quality => } \\
\text { Accounting Information } \\
\text { Quality }\end{array}$ & 0.369 & 0.372 & 0.109 & 3.399 & 0.001 \\
\hline $\begin{array}{l}\text { Intemal Control } \\
\Rightarrow \text { Accounting } \\
\text { Information System } \\
\text { Quality }\end{array}$ & 0.581 & 0.575 & 0.069 & 8.461 & 0.000 \\
\hline $\begin{array}{l}\text { Organizational } \\
\text { Commitment => } \\
\text { Accounting Information } \\
\text { System Quality }\end{array}$ & 0.404 & 0.410 & 0.069 & 5.826 & 0.000 \\
\hline
\end{tabular}

H1 : Organizational Commitment has a positive and significant effect on Accounting Information System Quality. Based on table 4.4 above, it can be seen that organizational commitment has a positive and significant effect $(\mathrm{O}=$ 0.404) on Accounting Information System Quality. The t-statistic value in this variable relationship is 5,826>1,972, and p-value is $0,000<0.05$. Therefore, this research proves that there is a positive and significant effect between Organizational Commitment and Accounting Information System Quality. 
Devi Eryana \& Fardinal., Sch Bull, Dec 2019; 5(12): 734-742

\begin{tabular}{|c|c|c|c|c|c|}
\hline Variable & $\begin{array}{c}\text { Original } \\
\text { Sample } \\
\text { (O) }\end{array}$ & $\begin{array}{c}\text { Sample } \\
\text { Mean (M) }\end{array}$ & $\begin{array}{l}\text { Standard } \\
\text { Deviation } \\
\text { (STDEV) }\end{array}$ & $\begin{array}{l}\text { T Statistics } \\
\text { (O/STDEV) }\end{array}$ & $\begin{array}{c}\mathbf{P} \\
\text { Values }\end{array}$ \\
\hline $\begin{array}{l}\text { Accounting Information } \\
\text { System Quality => } \\
\text { Accounting Information } \\
\text { Quality }\end{array}$ & 0.369 & 0.372 & 0.109 & 3.399 & 0.001 \\
\hline $\begin{array}{l}\text { Internal Control } \\
\Rightarrow>\text { Accounting } \\
\text { Information System } \\
\text { Quality }\end{array}$ & 0.581 & 0.575 & 0.069 & 8.461 & 0.000 \\
\hline $\begin{array}{l}\text { Organizational } \\
\text { Commitment } \Rightarrow> \\
\text { Accounting Information } \\
\text { System Quality }\end{array}$ & 0.404 & 0.410 & 0.069 & 5.826 & 0.000 \\
\hline Variable & $\begin{array}{c}\text { Original } \\
\text { Sample } \\
\text { (O) }\end{array}$ & $\begin{array}{c}\text { Sample } \\
\text { Mean (M) }\end{array}$ & $\begin{array}{l}\text { Standard } \\
\text { Deviation } \\
\text { (STDEV) }\end{array}$ & $\begin{array}{l}\text { T Statistics } \\
\text { (O/STDEV) }\end{array}$ & $\begin{array}{c}\text { P } \\
\text { Values }\end{array}$ \\
\hline $\begin{array}{l}\text { Accounting Information } \\
\text { System Quality } \Rightarrow> \\
\text { Accounting Information } \\
\text { Quality }\end{array}$ & 0.369 & 0.372 & 0.109 & 3.399 & 0.001 \\
\hline $\begin{array}{l}\text { Internal Control } \\
\text { =>Accounting } \\
\text { Information System } \\
\text { Quality }\end{array}$ & 0.581 & 0.575 & 0.069 & 8.461 & 0.000 \\
\hline $\begin{array}{l}\text { Organizational } \\
\text { Commitment }=> \\
\text { Accounting Information } \\
\text { System Quality }\end{array}$ & 0.404 & 0.410 & 0.069 & 5.826 & 0.000 \\
\hline
\end{tabular}

H2 : Internal Control has a positive and significant effect on Accounting Information System Quality. Internal Control Variable has a positive and significant effect $(\mathrm{O}=0.581)$ on Accounting Information System Quality variable. The t-statistic value in this variable relationship is $8,461>1,972$, and p-value is $0,000<0.05$. Therefore, this research proves that there is a positive and significant effect of Internal Control on Accounting Information System Quality.

H3 : Accounting Information System Quality has a positive and significant effect on Accounting Information Quality. Accounting Information System Quality Variable has a positive and significant effect $(\mathrm{O}=0.369)$ on Accounting Information Quality variable. This value is based on the t-statistic value in this variable relationship with 3,399> 1,972, and the p-value is $0.001<0.05$. Therefore, this research proves there is a positive and significant effect of Accounting Information System Quality on Accounting Information Quality.

\section{CONCLUSION}

The conclusions are as follow:

- Organizational Commitment has a positive and significant effect on Accounting Information System Quality. This value is seen from Path Coefficient output obtained by $\mathrm{t}$ count $>\mathrm{t}$ table $(5.826>1.972)$ or $p$-value $<0.05(0.000<0.05)$, so, Ho is rejected. The coefficient value (Original sample column) is positive at 0.404 meaning it has a positive effect.

- Internal Control has a positive and significant effect on Accounting Information System Quality. This value can be seen from Path Coefficient output obtained by $t$ count $>\mathrm{t}$ table $(8.461>1.972)$ or p-values $<0.05(0.000<0.05)$, so, Ho is rejected. The coefficient value (Original sample column) is positive at 0.581 meaning it has a positive effect.

- Accounting Information System Quality has a positive and significant effect on Accounting Information Quality. This value is seen from Path Coefficient output obtained by $\mathrm{t}$ count $>\mathrm{t}$ table (3.399> 1.972) or p-values <0.05 $(0.001<0.05)$, so, Ho is rejected. The coefficient value (Original sample column) is positive at 0.369 meaning it has a positive effect.

\section{REFERENCES}

1. Sugiyono, M. P. P. (2016). Pendekatan Kuantitatif, Kualitatif, dan R \& D (cetakan ke-23). Bandung: Alfabeta.

2. Bodnar, G.H., Hopwood, S.B.(2010). Accounting Information Systems. Tenth Edition. USA: Pearson Education, Inc.

3. Hall, J. (2011). Sistem Informasi Akuntansi, Edisi Empat. Jakarta : Salemba Empat.

4. Azhar, S. (2017). Sistem Informasi Akuntansi: Pemahaman Konsep Secara Terpadu. Cetakan Pertama. Bandung: Lingga Jaya.

5. Sacer, Ivana, M., Zager K., \& Tusek, B. (2006). Accounting Information System's Quality as The 
Ground For Quality Business Reporting. IADIS International Conference - commerce, ISBN:9728924-232-2.

6. Tjakrawala, F. X., \& Cahyo, A. (2010). Adaptasi Model Delone \& Mclean Yang Dimodifikasi Guna Menguji Keberhasilan Implementasi Software Akuntansi Bagi Individu Pengguna: Studi Empiris Pada Perusahaan Dalam Industri Barang Konsumsi Yang Terdaftar Di Bei. SNA XIII Purwokerto.

7. Larsen, K. R. (2003). A taxonomy of antecedents of information systems success: variable analysis studies. Journal of Management Information Systems, 20(2), 169-246.

8. Wulan, W., Kirmizi., \& Restu, A. (2015). Pengaruh Komitmen Organisasi Dan Pengetahuan Manajer Terhadap Keberhasilan Penerapan Sistem Informasi Akuntansi. Jurnal Akuntansi Universitas Riau, 3(2).

9. Aceng Kurniawan dan Meilani Purwanti. (2017). Pengaruh Pengendalian Internal Terhadap Kualitas Sistem Informasi Akuntansi Dan Dampaknya Terhadap Kualitas Informasi Akuntansi. Study \& Accounting Research.

10. Karma, C. (2012). Lemahnya SPI, Mudahkan Terjadinya Korupsi. Diakses dari http://tabloidjubi.com/2012/11/28/lemahnya-spimudahkan-terjadinya-korupsi/

11. Azhar, S. (2017). The Influence of Organizational Commitment on the Quality Accounting Information System. International Journal of Scientific and Technology Research.

12. O'Brien, J. A. dan Marakas, G. M. (2012). Introduction To Information Systems. 16th Edition. New York: McGraw-Hill Companies, Inc.

13. Romney dan Steinbart. (2015). Sistem Informasi Akuntansi: Accounting Information Systems. Edisi 13. Jakarta: Salemba Empat.

14. Azmi Fitriati dan Sri Mulyani. (2015). Factors That Affect Accounting Information System Success and its Implication on Accounting Information Quality. Asian Journal of Information Technology.

15. Stair, M. Ralph dan George W. Reynolds. (2015). Principles of Information Systems A Managerial Approach. 12th Edition. USA: Course Technology, Cengage Learning.

16. Laudon, Kenneth, C. dan Laudon, Jane, P. (2017). Management Information Systems - Managing The Digital Firm. 15th Edition. Pearson Prentice Hall.

17. William, H., DeLone dan Ephraim, R., McLean. (2016). Information Systems Success Measurement, 2. United States: Acid-free Paper.

18. Wixom, B. H., \& Todd, P. A. (2005). A theoretical integration of user satisfaction and technology acceptance. Information systems research, 16(1), 85-102.

19. Baltzan, P. (2012). Business Driven Information Systems. Third Edition. New York: McGraw Hill. International Edition.
20. Gelinas, J.U.1. (2012). Accounting Information Systems. South Western: Cengage Learning.

21. Sulistyoningsih. (2006). Analisis Kualitas Informasi Akuntansi. Jurnal Sistem Informasi Akuntansi Vol.5 no 3 hal 69.

22. Sekaran, Uma dan R.B. (2011). Research Methods for Business, A Skill Building Approach. 5th edition, New York: John Wiley and Sons, Ltd Publication.

23. Nunung, N. (2014). Influence Of Organizational Commitment and Knowledge Management on Successful Imolementation of Accounting Information Systems. International Journal of Economics, Commerce and Management.

24. Taufik, A. (2018). Pengaruh Budaya Organisasi dan Struktur Organisasi terhadap Kualitas Informasi Akuntansi dengan Kualitas Sistem Informasi Akuntansi sebagai variabel Intervening. Profita Journal at Mercu Buana University.

25. Fardinal. (2013). The Quality of Accounting Information and The Accounting Information System through The Internal Control Systems: A Study on Ministry and State Agencies of The Republic of Indonesia. Research Journal of Finance and Accounting.

26. Rapina. (2014). Factors Influencing The Quality of Accounting Information System And Its Implications on The Quality of Accounting Information. Research Journal of Finance and Accounting.

27. Mayer, J. P., Allen, N. J., \& Smith, C. A. (1993). Commitment to organizations and occupations: extension and test of a three-component conceptualization. Journal of Applied Psychology, 78(4), 538-551.

28. Rapina. (2015). Factors that Affect Accounting Information Systems and Accounting Information. Australian Journal of Basic and Applied Sciences.

29. Yenni, C. (2014). Organizational Factors and Accounting Information System Quality. Research Journal of Finance and Accounting.

30. Colquitt, J. L., Pickett, K., Loveman, E., \& Frampton, G. K. (2014). Surgery for weight loss in adults. Cochrane database of systematic reviews, (8).

31. Rapina. (2015). The Effect of Organizational Commitment and Organizational Culture on Quality of Accounting Information Mediated by Quality of Accounting Information System. International Journal of Applied Business and Economic Research.

32. Ramdany. (2015). Influence The Quality of Accounting Information Systems and The Effectiveness of Internal Control On Financial Reporting Quality. Research Journal of Finance and Accounting

33. Haryono, S. (2017). Metode SEM Untuk Penelitian Manajemen dengan AMOS Lisrel PLS, Cetakan I. Jakarta: Luxima Metro Media. 
34. Mulyadi. (2016). Sistem Akuntansi. Jakarta: Salemba Empat.

35. OECD. (2013). PISA 2012 Results: Executive Summary. New York: Colimbia University.

36. Syafrida, D.R. (2017). Pengaruh Aktivitas Pengendalian, Informasi dan Komunikasi terhadap Kualitas Sistem Informasi Akuntansi dan Dampaknya Terhadap Kualitas Laporan Keuangan. Profita Journal at Mercu Buana University.

37. Hahn, M., Lawson, R., and Lee, Y.G. (1992). The Effects of Time Pressure and Information Load on Decision Quality. Psychology and Marketing,9 (5): 365-378.

38. Almalia, L. S., \& Briliantine, I. (2007). Analisis Faktor Faktor Yang Mempengaruhi Kinerja Sistem Informasi Akuntansi Pada Bank Umum Pemerintah di wilayah Surabya dan Sidoarjo. STIE Perbanas Surabaya.
39. Franta, E. (2016). Pengaruh SAP Berbasis Akrual, Sistem Informasi Akuntansi, Kualitas SDM, Pengendalian Internal dan Komitmen Organisasi terhadap Kualitas Laporan Keuangan. Media Riset Akuntansi, Auditing \& Informasi.

40. Winda, R. (2015). Pengaruh Kemampuan Pengguna dan Pengendalian Intern terhadap Kualitas Sistem Informasi Akuntansi. Publiser

41. Kothari, C. R. (2004). Research methodology: Methods and techniques. New Age International.

42. Suriasumantri, J. S. (2010). Menguak Cakrawala Keilmuan.

43. Suharsimi, A. (2016). Prosedur Penelitian Suatu Pendekatan Praktik. Jakarta: Rineka Cipta.

44. Juliansyah, N. (2012). Metode Penelitian: Skripsi, Tesis, Disertasi dan Karya Ilmiah. Cetakan Kedua. Jakarta: Kencana. 